\title{
Seven new species of the genus Carpelimus Leach, 1819 from the "taprobanae" group (Coleoptera: Staphylinidae: Oxytelinae)
}

\author{
Семь новых видов рода Carpelimus Leach, 1819 из группы \\ "taprobanae" (Coleoptera: Staphylinidae: Oxytelinae)
}

\author{
M.Yu. Gildenkov \\ М.Ю. Гицьденков
}

Smolensk State University, Przhevalsky str. 4, Smolensk 214000, Russia. E-mail: mgildenkov@mail.ru
Смоленский государственный университет, Пржевальского 4, Смоленск 214000, Россия.

KEY WORDS: Coleoptera, Staphylinidae, Carpelimus, new species, Oriental region, Vietnam, India, Nepal. КЛЮчЕВЫЕ СЛОВА: Coleoptera, Staphylinidae, Carpelimus, новые виды, Восточная биогеографическая область, Вьетнам, Индия, Непал.

ABSTRACT: Seven new species of the genus Carpelimus from the "taprobanae" species group are described from the Oriental biogeographic region: Carpelimus (Trogophloeus) cachariensis, sp.n., Carpelimus (Trogophloeus) finelypunctus, sp.n., Carpelimus (Trogophloeus) khasiensis, sp.n., Carpelimus (Trogophloeus) keraliensis, sp.n. and Carpelimus (Trogophloeus) madrasiensis, sp.n. from India, Carpelimus (Trogophloeus) hoaensis, sp.n. from Vietnam and Carpelimus (Trogophloeus) mustangiensis, sp.n. from Nepal.

РЕЗЮМЕ: Описываются семь новых видов рода Carpelimus группы “taprobanae" из Восточной биогеографической области: Carpelimus (Trogophloeus) cachariensis, sp.n., Carpelimus (Trogophloeus) finelypunctus, sp.n., Carpelimus (Trogophloeus) khasiensis, sp.n., Carpelimus (Trogophloeus) keraliensis, sp.n. и Carpelimus (Trogophloeus) madrasiensis, sp.n. из Индии, Carpelimus (Trogophloeus) hoaensis, sp.n. из Вьетнама и Carpelimus (Trogophloeus) mustangiensis, sp.n. из Непала.

\section{Introduction}

The members of the genus Carpelimus Leach, 1819 that belong to the "taprobanae" species group are quite common in the Oriental biogeographic region and can often be clearly distinguished only by the details of the structure of their aedeagus. The highest diversity of these species is found in India. This group now includes 11 species: Carpelimus (Trogophloeus) taprobanae (Walker, 1859), C. lepidicornis (Fauvel, 1904), C. nitidipennis (Cameron, 1919), C. granulatus (Cameron,
1930), C. vagans (Cameron, 1930), C. cataractus Gildenkov, 2014, C. flavomustachus Gildenkov, 2014, $C$. holosericus Gildenkov, 2014, C. magnicollis Gildenkov, 2014, C. asperus Gildenkov, 2018, and C. geminus Gildenkov, 2018. The present study is a continuation of a series of papers on the genus Carpelimus for the Oriental biogeographic region and, specifically, on the "taprobanae" species group [Gildenkov, 2014, 2015, 2018, 2019].

This paper is based on the specimens deposited in the following collections: $\mathrm{cMG}$ private collection of $\mathrm{M}$. Gildenkov (Smolensk, Russia); FMNH Field Museum of Natural History (Chicago, USA); HNHM Hungarian Natural History Museum (Budapest, Hungary); MHNG Museum d'Histoire Naturelle Geneva (Switzerland); NHMW Naturhistorisches Museum Wien (Austria); SMNS Staatliches Museum für Naturkunde in Stuttgart (Germany). In the present study, standard methods were used for the taxonomic research of insects; the preparations were made on an MBS-10 binocular microscope. The genital preparations were processed using $10 \% \mathrm{KOH}$ and then fixed in euparal. In the descriptions and diagnoses giving the length to width ratio for the head, pronotum, and elytra, the following standard units were used: 7 standard units $=0.1 \mathrm{~mm}$; thus, 1 standard unit constitutes about $0.0143 \mathrm{~mm}$. Photographs were taken with a Canon EOS 5D Mark III camera and a Canon MPE $65 \mathrm{~mm}$ objective using the extended focus technology.

\section{Carpelimus (Trogophloeus) cachariensis} Gildenkov, sp.n.

Figs 1, 7-8.

MATERIAL. Holotype, o' "INDIA: Assam North Cachar Hills dist., Mt Borail, trail Jatinga-summit, 28.x.2004, $25^{\circ} 07^{\prime} 07^{\prime}$ ' $\mathrm{N}$,

How to cite this article: Gildenkov M.Yu. 2019. Seven new species of the genus Carpelimus Leach, 1819 from the "taprobanae" group (Coleoptera: Staphylinidae: Oxytelinae) // Russian Entomol. J. Vol.28. No.2. P.138 -145. doi: 10.15298/rusentj.28.2.04 
$93^{\circ} 02^{\prime} 13^{\prime \prime} \mathrm{E}$ " "650 m. at large, mixed broadleaf forest, R. Leschen, C. Carlton, G. Cuccodoro, D. Erne; RL-062 FIELD MUS. NAT. HIST." (FMNH). Paratype: $10^{7}$ "INDIA: Assam North Cachar Hills


"28.x.2004, Berlese various litters, C. Carlton, R. Leschen, G Cuccodoro, D. Erne; CC-029 FIELD MUS. NAT. HIST." (cMG).

\section{DESCRIPTION (holotype).}

Length $2.0 \mathrm{~mm}$. Colouration brown. Head, pronotum and elytra dark brown, abdomen dark brown; antennae light brown, legs, antennal segments 1 and 9-11 yellow brown. Integument slightly shining, body with short, light-coloured hairs.

Head transverse, with wide base, ratio of its length (from posterior margin of head to anterior margin of clypeus) to maximum width about 17:27. Neck constriction prominent. Eyes rather large, convex. Temples well-developed, round, eye diameter in dorsal view markedly longer but less than 1.5 times as long as temple length. Head about as wide across eyes as across temples (Fig. 1). Head surface with rather distinct, fine and dense punctation. Puncture diameter about twice as small as eye facet. Distances between punctures slightly smaller than their diameter, interspaces smooth, slightly shagreened. Antennae rather long, antennal segments $1-3$ and 5-6 elongate; segments 4-7 about as wide as long; segments $8-10$ slightly transverse; segment 11 elongate, conical. Last 3 segments more massive than others and form loose club (Fig. 1).

Pronotum widest about $2 / 3$ its length from base, then narrowed. Lateral margins slightly notched at base, then smoothly rounded (Fig. 1). Ratio of pronotum length to its maximum width about 22:32. Surface of pronotum with rather distinct, fine and dense punctation; punctation similar to that on head. Puncture diameter about twice as small as eye facet. Distances between punctures significantly smaller than their diameter, interspaces slightly shagreened. Pronotal disc with 2 pairs of barely discernible, symmetrical depressions, round at base and oval in central part of disc (Fig. 1).

Ratio of length of elytra to their combined width about 34:38. Scutellum with shallow, round depressions (Fig. 1). Surface of elytra with rather distinct, fine and dense punctation. Puncture diameter about equal to diameter of eye facet. Distances between punctures slightly smaller than their diameter, interspaces smooth, slightly shining.

Abdomen delicately shagreened.

Aedeagus of characteristic structure (Figs 7-8).
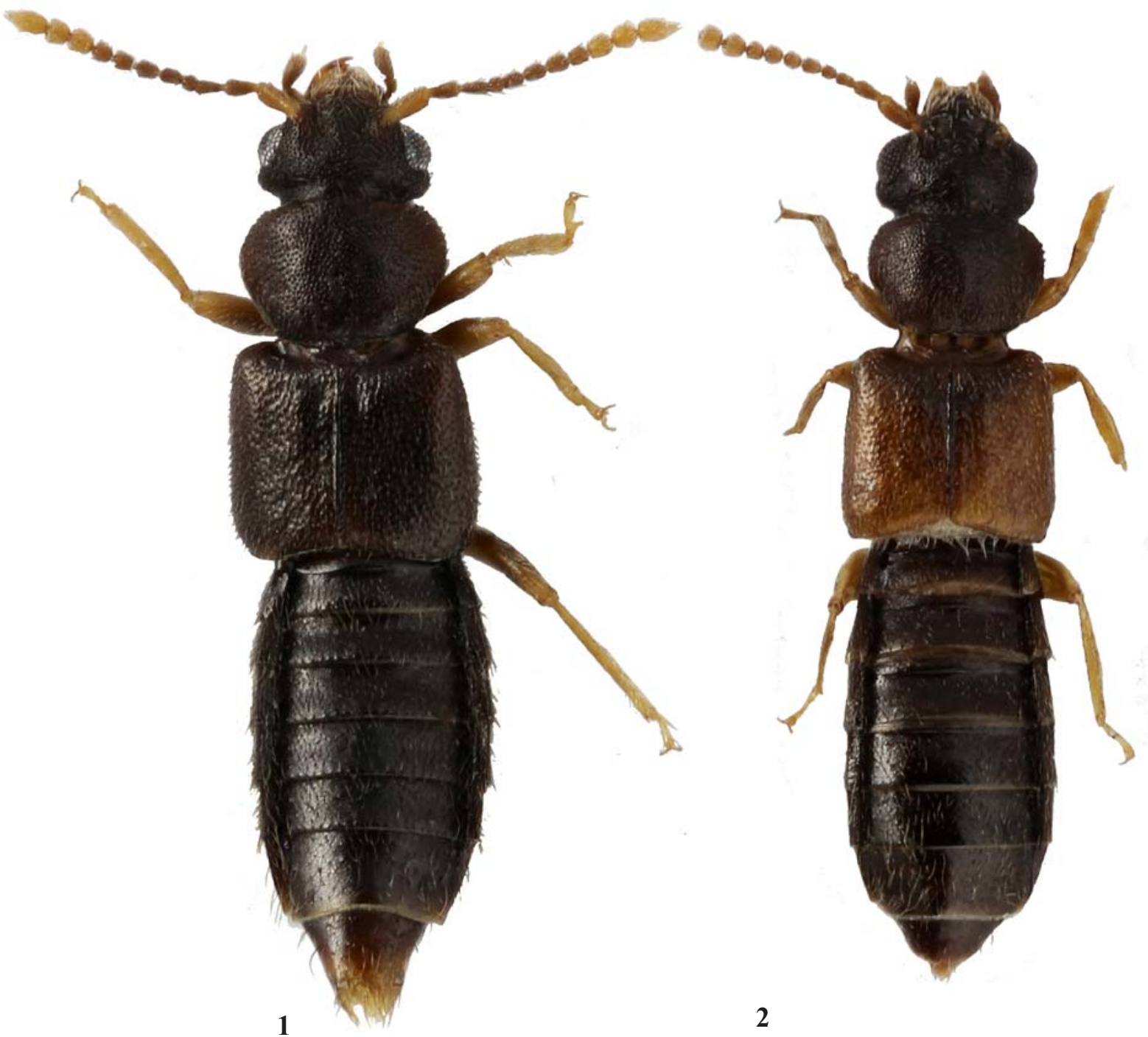

Figs 1-2. Carpelimus (Trogophloeus) spp., holotypes, males, dorsal view: $1-$ C. cachariensis, sp.n.; $2-$ C. finelypunctus, sp.n. Рис. 1-2. Carpelimus (Trogophloeus) spр., глотипы, самцы, сверху: $1-$ C. cachariensis, sp.n.; $2-$ C. finelypunctus, sp.n. 
Female unknown.

COMPARATIVE REMARKS. The new species is most similar in size, morphology of the pronotum, colouration and punctation patterns to closely related species, C. magnicollis Gildenkov, 2014 and $C$. keraliensis sp.n. The new species differs from C. magnicollis in its smaller size and less prominent eyes and is clearly distinguished by the structure of the aedeagus [Gildenkov, 2015, p. 385, Figs 19: 45]. It differs from C. keraliensis sp.n. in having less prominent eyes, slightly less distinct punctation on the pronotum and is clearly differentiated from it by the structure of the aedeagus (Figs 7$8,15-16)$

DISTRIBUTION. India.

ETYMOLOGY. Named for its geographical distribution.

\section{Carpelimus (Trogophloeus) finelypunctus Gildenkov, sp.n.}

Figs 2, 9-11.

MATERIAL. Holotype, $\sigma^{7}$ "INDIA Kerala Palghat Hills $10 \mathrm{~km}$ N. Malampuzha Dam 150 m. 27-XI-72 Besuchet Löbl Mussard" (MHNG). Paratype: 1 우 "INDIA Kerala Palghat Hills $10 \mathrm{~km} \mathrm{~N}$ Malampuzha Dam 150 m. 27-XI-72 Besuchet Löbl Mussard” (cMG)

DESCRIPTION (holotype)

Length $1.6 \mathrm{~mm}$. Colouration brown. Head, pronotum and abdomen dark brown, elytra much lighter, brown with reddish tint; legs and antennae yellow brown. Integument slightly shining, body with short, light-coloured hairs.

Head transverse, with wide base, ratio of its length (from posterior margin of head to anterior margin of clypeus) to maximum width about 15:23. Neck constriction prominent. Eyes large, convex. Temples well-developed, round, eye diameter in dorsal view markedly longer but less than 1.5 times as long as temple length. Head about as wide across eyes as across temples (Fig. 2). Head surface with delicate, very fine and dense punctation. Puncture diameter about 5 times as small as eye facet. Distances between punctures much smaller than their diameter, individual punctures barely discernible. Antennae rather long, antennal segments 1-3 and 5 elongate; segments 4 and 6-7 about as wide as long; segments 8-10 slightly transverse (Fig. 2); segment 11 (studied only in female) elongate, conical. Last 3 segments more massive than others and form loose club.

Pronotum widest about $2 / 3$ its length from base, then narrowed. Lateral margins straight from base, then broadly rounded (Fig. 2). Ratio of pronotum length to its maximum width about 18:24. Surface of pronotum with delicate, very fine and dense punctation. Puncture diameter about 5 times as small as eye facet. Distances between punctures significantly smaller than their diameter, individual punctures barely discernible. Puncture patterns similar to those on head. Pronotal disc with barely discernible depressions: 2 faint, symmetrical oval depressions in central part of disc and small flattening at base of pronotum (Fig. 2).

Ratio of length of elytra to their combined width about 28:30. Scutellum with shallow, round depressions (Fig. 2) Surface of elytra with delicate, fine and dense punctation. Puncture diameter about equal to diameter of eye facet Distances between punctures slightly smaller than their diameter, interspaces smooth, slightly shining.

Abdomen delicately shagreened.

Aedeagus of characteristic structure (Figs 9, 10).

Female. Sexual dimorphism absent, female morphologically similar to male. Spermatheca of characteristic structure (Fig. 11)

COMPARATIVE REMARKS. The new species is most similar in size, colouration and punctation patterns to closely related species, C. vagans (Cameron, 1930) and C. hoaensis sp.n. The new species differs from $C$. vagans in having slightly smaller size, lighter colouration of the elytra, and finer punctation on the pronotum, and is clearly distinguished by the structure of the aedeagus [Gildenkov, 2015, p. 385, fig. 19: 13]. It differs from $C$. hoaensis sp.n. in having slightly smaller size, more prominent eyes, and finer punctation on the pronotum and is clearly differentiated from it by the structure of the aedeagus (Figs 9-10, 12-13).

DISTRIBUTION. India.

ETYMOLOGY. From the Latinised form of "finely punctured" referring to a very fine punctation on the surface of the head and pronotum.

\section{Carpelimus (Trogophloeus) hoaensis Gildenkov, sp.n.}

Figs 3, 12-14.

MATERIAL. Holotype, or "VIET NAM, Ha Son Bink. Hoa Binh" "Berlesate, No. 89 30.I.1986 Mahunka-01àh" (HNHM). Paratypes: $20^{\top} 0^{7}, 2$ 우 "VIET NAM, Ha Son Bink. Hoa Binh" "Berlesate, No. 89 30.I.1986 Mahunka-01àh" (HNHM; 107, 19 cMG).

DESCRIPTION (holotype).

Length $1.8 \mathrm{~mm}$. Colouration brown. Head, pronotum and abdomen dark brown, elytra much lighter, brown; legs and antennae yellow brown. Integument slightly shining, body with short, light-coloured hairs.

Head transverse, with wide base, ratio of its length (from posterior margin of head to anterior margin of clypeus) to maximum width about 16:24. Neck constriction prominent. Eyes small, slightly convex. Temples well-developed, round, eye diameter in dorsal view slightly smaller than temple length. Head widest across temples (Fig. 3). Head surface with rather distinct, fine and dense punctation. Puncture diameter about twice as small as eye facet. Distances between punctures slightly smaller than their diameter, interspaces slightly shagreened. Antennae rather short, antennal segments 1-3 elongate; segments $4-5$ about as wide as long; segments 6-7 slightly transverse; segments 8-10 transverse; segment 11 elongate, conical. Last 3 segments more massive than others and form loose club (Fig. 3).

Pronotum widest about $2 / 3$ its length from base, then narrowed. Lateral margins broadly rounded (Fig. 3). Ratio of pronotum length to its maximum width about 19:26. Surface of pronotum with rather distinct, fine and dense punctation. Puncture diameter about twice as small as eye facet. Distances between punctures slightly smaller than their diameter, interspaces slightly shagreened. Punctation patterns similar to those on head. Pronotal disc with 2 pairs of barely discernible, symmetrical depressions, round at base and oval in central part of disc (Fig. 3).

Ratio of length of elytra to their combined width about 25:33. Scutellum with shallow, round depressions (Fig. 3). Surface of elytra with rather distinct, fine and dense punctation. Puncture diameter about 1.5 times as long as eye facet. Distances between punctures slightly smaller than their diameter, interspaces smooth, slightly shining.

Abdomen delicately shagreened.

Aedeagus of characteristic structure (Figs 12-13).

Female. Sexual dimorphism absent, female morphologically similar to male. Spermatheca of characteristic structure (Fig. 14).

COMPARATIVE REMARKS. The new species is most similar in size, colouration and punctation patterns to closely related species, C. vagans (Cameron, 1930) and C. finelypunctus sp.n. The new species differs from $C$. vagans in having slightly larger punctation on the elytra and less prominent eyes and is clearly distinguished by the structure of the aedeagus [Gildenkov, 2015, p. 385, fig. 19: 13]. It differs 
from $C$. finelypunctus sp.n. in having slightly larger size, less prominent eyes, larger punctation on the pronotum and elytra and is clearly differentiated from it by the structure of the aedeagus (Figs 9-10, 12-13).

DISTRIBUTION. Vietnam.

ETYMOLOGY. Named for its geographical distribution.

\section{Carpelimus (Trogophloeus) keraliensis \\ Gildenkov, sp.n.}

Figs 4, 15-17.

MATERIAL. Holotype, $0^{7}$ "S-INDIEN: Kerala Cardamom Hills $10 \mathrm{~km}$ SW Kumily $77^{\circ} 07^{\prime} \mathrm{E} 09^{\circ} 31^{\prime} \mathrm{N}$ " "Vallakadavu. $1000 \mathrm{~m}$ 24.12.1993, leg. Boukai \& Kejval" (NHMW). Paratype: 1 우 "SINDIEN: Kerala Cardamom Hills 10km SW Kumily $77^{\circ} 07^{\prime}$ E $09^{\circ} 31^{\prime}$ N" "Vallakadavu. 1000m 24.12.1993, leg. Boukai \& Kejval" (cMG).

DESCRIPTION (holotype). Length $2.2 \mathrm{~mm}$. Colouration brown. Head, pronotum and abdomen dark brown, elytra slightly lighter, dark brown with reddish tint; legs and antennae yellow brown, antennal segments 911 lighter than others. Integument slightly shining, body with short, light-coloured hairs.

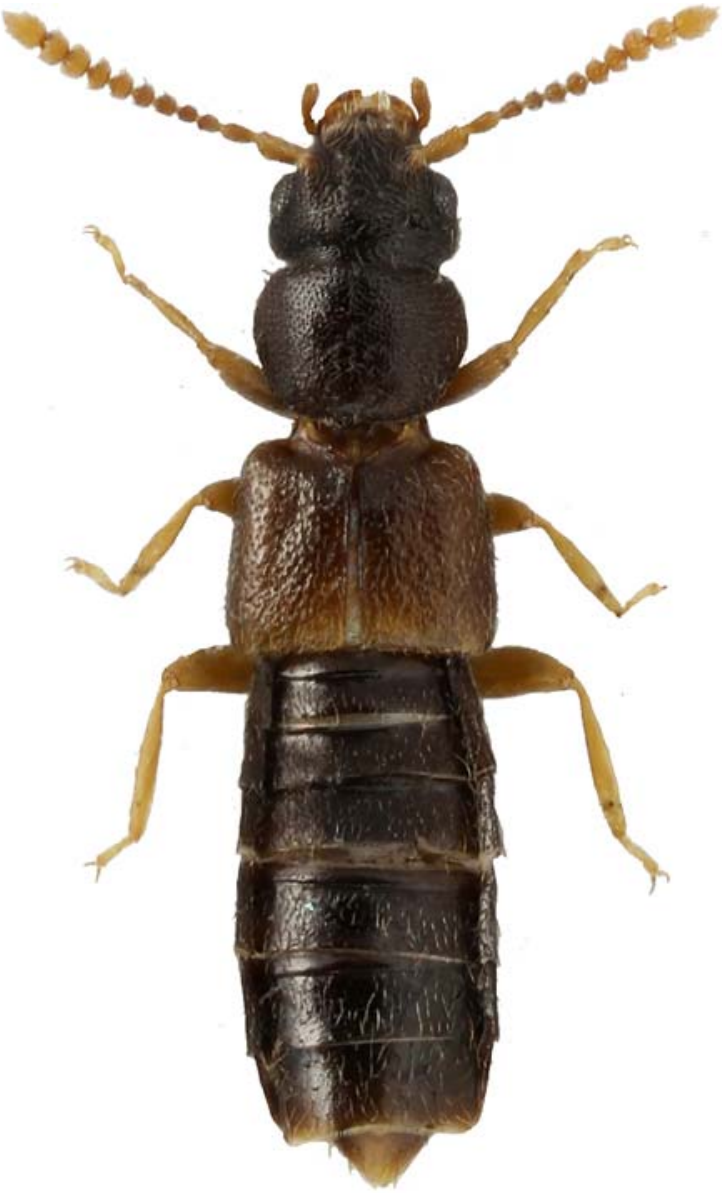

3
Head transverse, with wide base, ratio of its length (from posterior margin of head to anterior margin of clypeus) to maximum width about 18:29. Neck constriction prominent. Eyes large, convex. Temples well-developed, round, eye diameter in dorsal view more than twice as long as temple length. Head widest across eyes (Fig. 4). Head surface with rather distinct, fine and dense punctation. Puncture diameter about twice as small as eye facet. Distances between punctures significantly smaller than their diameter, interspaces smooth, slightly shining. Antennae rather long, antennal segments 1-6 elongate; segments 78 about as wide as long; segments 9-10 slightly transverse; segment 11 elongate, conical. Last 3 segments more massive than others and form loose club (Fig. 4).

Pronotum widest about $2 / 3$ its length from base, then narrowed. Lateral margins broadly rounded (Fig. 4). Ratio of pronotum length to its maximum width about 25:34. Surface of pronotum with distinct, fine and dense punctation; punctation similar to that on head. Puncture diameter about twice as small as eye facet. Distances between punctures significantly smaller than their diameter, interspaces smooth, slightly shin-

Figs 3-4. Carpelimus (Trogophloeus) spp., holotypes, males, dorsal view: $3-$ C. hoaensis, sp.n.; $4-$ C. keraliensis, sp.n.

Рис. 34. Carpelimus (Trogophloeus) spp., глотипы, самцы, сверху: 3 C. hoaensis, sp.n.; $4-$ C.keraliensis, sp.n.

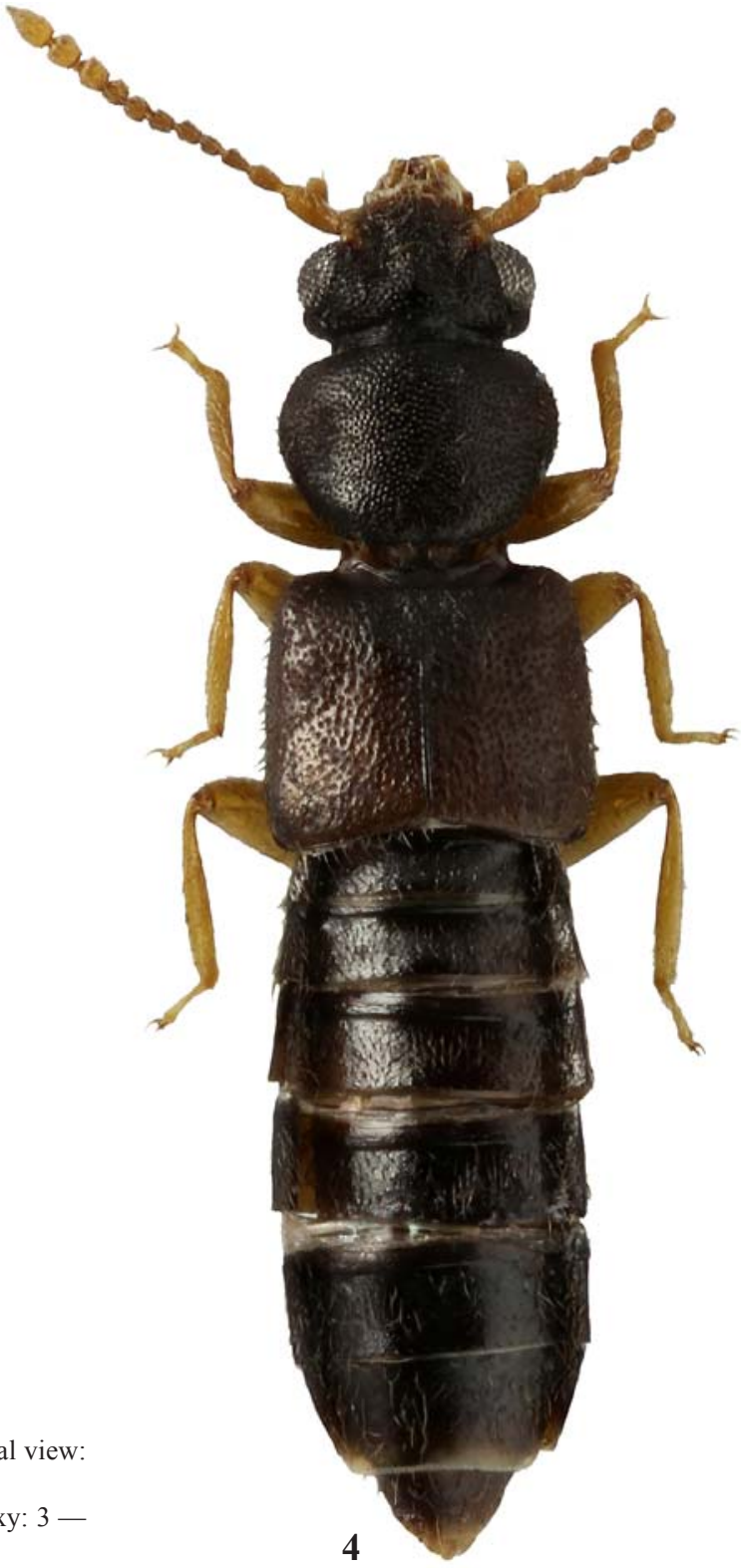


ing. Depressions on pronotal disc absent, except for small flattening at its base (Fig. 4).

Ratio of length of elytra to their combined width about 35:40. Scutellum with shallow, round depressions (Fig. 4). Surface of elytra with rather distinct, fine and dense punctation. Puncture diameter about equal to diameter of eye facet. Distances between punctures slightly smaller than their diameter, interspaces smooth, slightly shining.

Abdomen delicately shagreened.

Aedeagus of characteristic structure (Figs 15-16).

Female. Sexual dimorphism absent, female morphologically similar to male. Spermatheca of characteristic structure (Fig. 17)

COMPARATIVE REMARKS. The new species is most similar in size, the structure of the pronotum, colouration and punctation patterns to closely related species, $C$. magnicollis and $C$. cachariensis sp.n. The new species differs from $C$. magnicollis in having smaller size and is clearly distinguished by the structure of the aedeagus [Gildenkov, 2015, p. 385, Figs 19: 45]. It differs from C. cachariensis sp.n. in having slightly more distinct punctation on the surface of the pronotum and is clearly differentiated from it by the structure of the aedeagus (Figs 7-8, 15-16).

DISTRIBUTION. India.

ETYMOLOGY. Named for its geographical distribution.

\section{Carpelimus (Trogophloeus) khasiensis \\ Gildenkov, sp.n.}

Figs 5, 18-19.

MATERIAL. Holotype, $\sigma^{7}$ "INDIA Meghalaya: East Khasi Hills dist., Cherrapunjee, below Mawmluh, 25 $5^{\circ} 14^{\prime} 59^{\prime \prime}$ N, $91^{\circ} 41^{\prime} 52^{\prime}$ ', E, 1200 m." "24.x.2004, Berlese broad-leaf litter, C. Carlton, R. Leschen, G. Cuccodoro, D. Erne; CC-017 FIELD MUS. NAT. HIST." (FMNH)

DESCRIPTION (holotype).

Length $2.0 \mathrm{~mm}$. Colouration dark brown, antennae brown, legs and antennal segment 1 light brown. Integument slightly shining, body with short, light-coloured hairs.

Head transverse, with wide base, ratio of its length (from posterior margin of head to anterior margin of clypeus) to maximum width about 18:25. Neck constriction prominent. Eyes rather large, slightly convex. Temples well-developed, round, eye diameter in dorsal view only slightly longer than

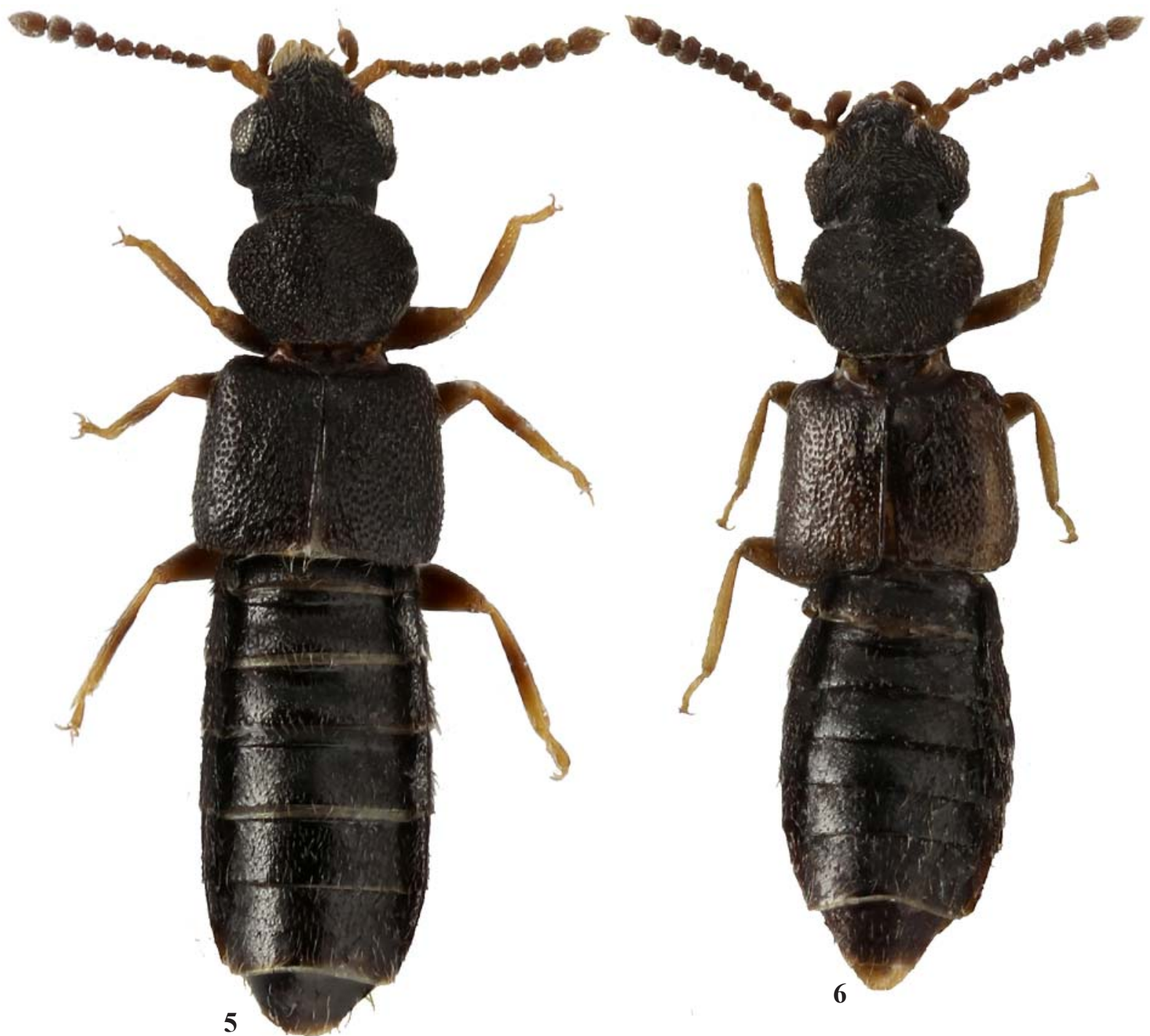

Figs 5-6. Carpelimus (Trogophloeus) spp., holotypes, males, dorsal view: 5 - C. khasiensis, sp.n.; 6 - C. madrasiensis, sp.n. Рис. 5-6. Carpelimus (Trogophloeus) spр., глотипы, самцы, сверху: 5 - C. khasiensis, sp.n.; 6 - C. madrasiensis, sp.n. 

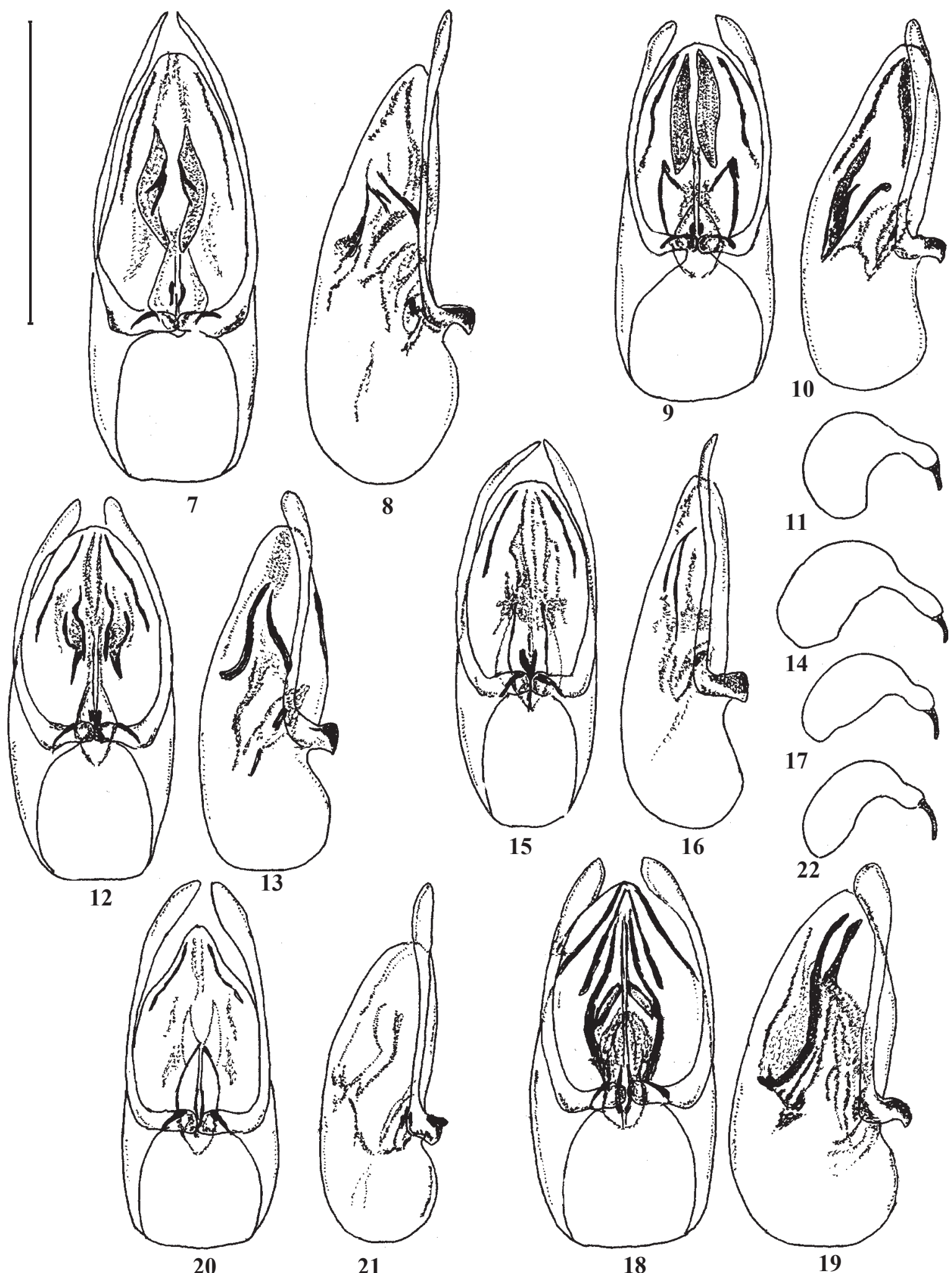

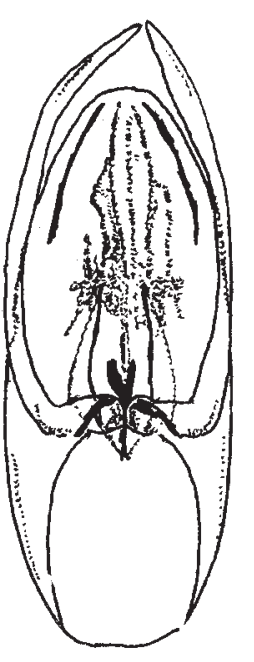

15

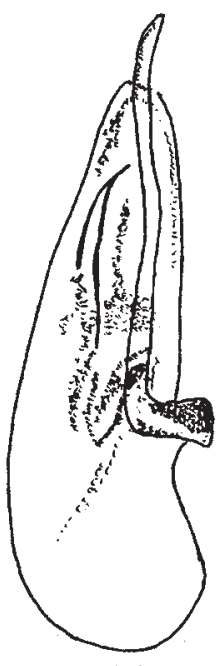

16

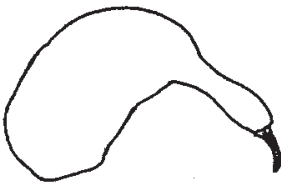

14

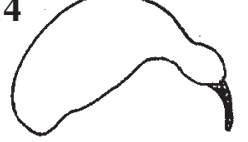

17

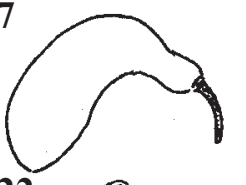

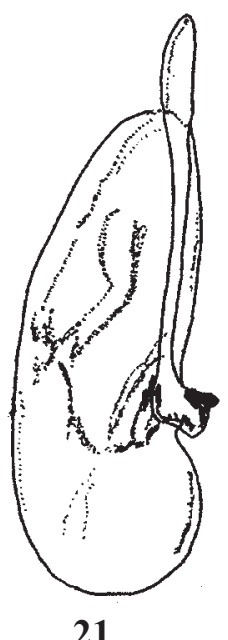

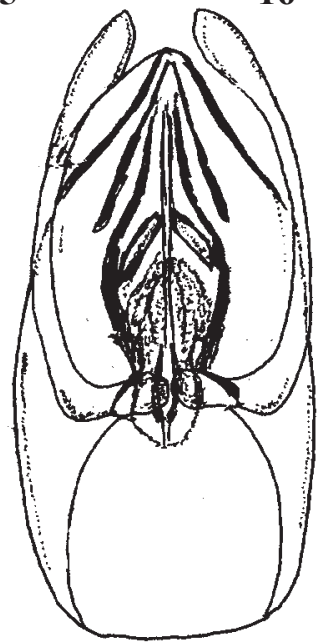

18

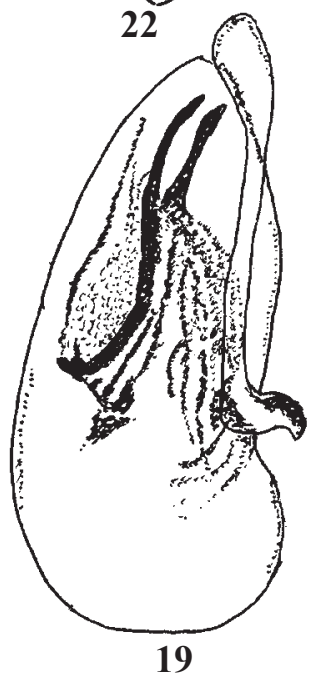

Figs 7-22. Genitalia of Carpelimus (Trogophloeus) spp.: 7-8 - C. cachariensis sp.n.; 9-11-C. finelypunctus sp.n.; 12-14 - C. hoaensis sp.n.; 15-17-C. keraliensis sp.n.; 18-19-C. khasiensis sp.n.; 20-22-C. madrasiensis sp.n.; 7, 9, 12, 15, 18, 20 - aedeagus, ventral view (holotypes); 8, 10, 13, 16, 19, 21 - aedeagus, lateral view (holotypes); 11, 14, 17, 22 — spermatheca (paratypes). Scale bar: 0.25 mm.

Рис. 7-22. Гениталии Carpelimus (Trogophloeus) spp.: 7-8 - C. cachariensis sp.n.; 9-11- C. finelypunctus sp.n.; 12-14 - C. hoaensis sp.n.; 15-17 - C. keraliensis sp.n.; 18-19 - C. khasiensis sp.n.; 20-22 - C. madrasiensis sp.n.; 7, 9, 12, 15, 18, 20 - эдеагус, снизу (голотипы); 8, 10, 13, 16, 19, 21 - эдеагус, сбоку (голотипы); 11, 14, 17, 22 — сперматека (паратипы). Масштаб: 0.25 тm. 
temple length. Head about as wide across eyes as across temples (Fig. 5). Head surface densely and coarsely shagreened; large and dense punctation barely discernible only on vertex. Antennae rather short, antennal segments 1-3 elongate; segments 45 about as wide as long; segments 6-10 slightly transverse; segment 11 elongate, conical. Last 3 segments more massive than others and form loose club (Fig. 5).

Pronotum widest about $2 / 3$ its length from base, then narrowed. Lateral margins straight from base, then broadly rounded (Fig. 5). Ratio of pronotum length to its maximum width about 19:28. Surface of pronotum densely and coarsely shagreened. Base of pronotal disc with barely discernible symmetrical, round depressions (Fig. 5).

Ratio of length of elytra to their combined width about 30:34. Scutellum with shallow, round depressions (Fig. 5). Surface of elytra with rather distinct, fine and dense punctation. Puncture diameter about equal to diameter of eye facet. Distances between punctures significantly smaller than their diameter, interspaces smooth, slightly shining.

Abdomen delicately shagreened.

Aedeagus of characteristic structure (Figs 18-19).

Female unknown.

COMPARATIVE REMARKS. The new species is most similar in size, colouration, and in densely and coarsely shagreened surface of the head and pronotum to a closely related species, $C$. mustangiensis sp.n., but is clearly distinguished from it by the structure of the aedeagus (Figs 18-19, 24-25).

DISTRIBUTION. India.

ETYMOLOGY. Named for its geographical distribution.

\section{Carpelimus (Trogophloeus) madrasiensis Gildenkov, sp.n.}

Figs 6, 20-22.

MATERIAL. Holotype, o " "INDIA 53 Madras Amaravathi Dam. $20 \mathrm{~km}$. S. d'udamalpet $400 \mathrm{~m}$. 26-XI-72 Besuchet Löbl Mussard" (MHNG). Paratypes: $20^{7} 0^{7}, 4$ 우우 "INDIA 53 Madras Amaravathi Dam. 20 km. S. d'udamalpet $400 \mathrm{~m}$. 26-XI-72 Besuchet Löbl Mussard' (MHNG; 10?, 1 cMG); 1ㅇ "INDIA Madras Anaimalai H. 18 km N. de Valparai 1250 m. 18-XI-72 Besuchet Löbl Mussard" (MHNG).

DESCRIPTION (holotype).

Length $1.9 \mathrm{~mm}$. Colouration dark brown. Head, pronotum, abdomen and antennae dark brown, elytra slightly lighter, dark brown; legs and antennal bases light brown. Integument slightly shining, body with short, light-coloured hairs.

Head transverse, with wide base, ratio of its length (from posterior margin of head to anterior margin of clypeus) to maximum width about 17:25. Neck constriction prominent. Eyes rather large, convex. Temples well-developed, round, eye diameter in dorsal view about 1.5 times as long as temple length. Head about as wide across eyes as across temples (Fig. 6). Head surface densely shagreened. Antennae rather short, antennal segments 1-3 elongate; segments 4-5 about as wide as long; segments 6-10 transverse; segment 11 elongate, conical. Last 3 segments more massive than others and form loose club (Fig. 6).

Pronotum widest about $2 / 3$ its length from base, then narrowed. Lateral margins slightly notched at base, then broadly rounded (Fig. 6). Ratio of pronotum length to its maximum width about 20:27. Surface of pronotum densely shagreened. Depressions on pronotal disc absent, except for small flattening at its base (Fig. 6)

Ratio of length of elytra to their combined width about 30:33. Scutellum with shallow, round depressions (Fig. 6). Surface of elytra with rather distinct, fine and dense punctation. Puncture diameter about equal to diameter of eye facet. Distances between punctures significantly smaller than their diameter, interspaces smooth, slightly shining.
Abdomen delicately shagreened.

Aedeagus of characteristic structure (Figs 20-21).

Female. Sexual dimorphism absent, female morphologically similar to male. Spermatheca of characteristic structure (Fig. 22).

COMPARATIVE REMARKS. The new species is most similar in size and in densely shagreened surface of the head and pronotum to closely related species, C. flavomustachus and $C$. asperus. It differs from them in having darker colouration and is clearly distinguished by the structure of the aedeagus [Gildenkov, 2015, p. 384, Figs 18: 12-13; Gildenkov, 2018, p. 139, Figs 56]. The new species differs from $C$. khasiensis sp.n. and C. mustangiensis sp.n. in having lighter colouration, more delicately shagreened surface of the head and pronotum and in the structure of the aedeagus (Figs 18$21,24-25)$.

DISTRIBUTION. India.

ETYMOLOGY. Named for its geographical distribution.

\section{Carpelimus (Trogophloeus) mustangiensis Gildenkov, sp.n.} Figs 23-25.

MATERIAL. Holotype, ơ "Nepal 435 Mustang Distr., right banks of Lethe Khola near Lethe, 2400m, 5-7.V.1995 MARTENS \& SCHAWALLER" (SMNS).

DESCRIPTION (holotype).

Length $2.2 \mathrm{~mm}$. Colouration dark, legs and antennae brown, antennal segments 12 and 11, tarsi, tibial bases and apices light brown. Integument slightly shining, body with short, light-coloured hairs.

Head transverse, with wide base, ratio of its length (from posterior margin of head to anterior margin of clypeus) to maximum width about 18:25. Neck constriction prominent. Eyes rather large, slightly convex. Temples well-developed, round, eye diameter in dorsal view markedly longer, but less than 1.5 times as long as temple length. Head about as wide across eyes as across temples (Fig. 23). Head surface densely and coarsely shagreened; fine, dense punctation barely discernible only on vertex. Antennae rather short, antennal segments 1-3 elongate; segments 4-5 about as wide as long; segments 6-7 slightly transverse; segments $8-10$ transverse; segment 11 elongate, conical. Last 3 segments more massive than others and form loose club (Fig. 23).

Pronotum widest about $2 / 3$ its length from base, then narrowed. Lateral margin slightly notched at base, then broadly rounded (Fig. 23). Ratio of pronotum length to its maximum width about 21:28. Surface of pronotum densely and coarsely shagreened. Base of pronotal disc with barely discernible, symmetrical, round depressions (Fig. 23).

Ratio of length of elytra to their combined width about 33:38. Scutellum with shallow, round depressions (Fig. 23). Surface of elytra with rather distinct, fine and dense punctation. Puncture diameter about equal to diameter of eye facet. Distances between punctures significantly smaller than their diameter, interspaces smooth, slightly shining.

Abdomen delicately shagreened.

Aedeagus of characteristic structure (Figs 24-25).

Female unknown.

COMPARATIVE REMARKS. The new species is most similar in size, colouration and in coarsely shagreened surface of the head and pronotum to a closely related species, $C$. khasiensis sp.n. and is clearly distinguished by the structure of the aedeagus (Figs 18-19, 24-25).

DISTRIBUTION. Nepal.

ETYMOLOGY. Named for its geographical distribution. 

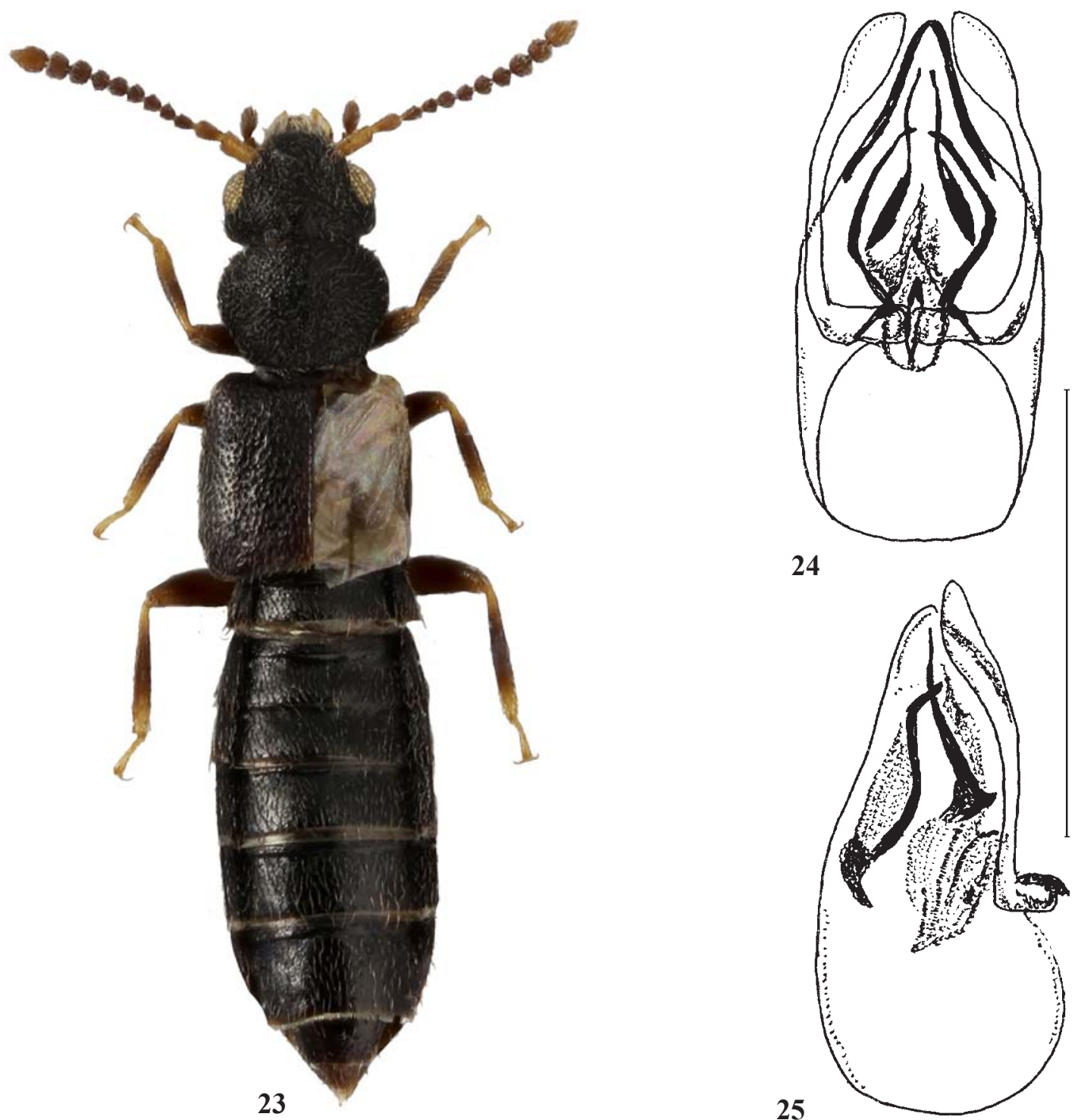

Figs 23-25. Carpelimus (Trogophloeus) mustangiensis, sp.n., holotype, male: 23 - habitus, dorsal view; 24 - aedeagus, ventral view; 25 - aedeagus, lateral view. Scale bar: $0.25 \mathrm{~mm}$.

Рис. 23-25. (Trogophloeus) mustangiensis, sp.n.,, sp.n., голотип, самец: 23 - габитус, сверху; 24 - эдеагус, снизу; 25 - эдеагус, сбоку. Масштаб: $0.25 \mathrm{~mm}$.

Acknowledgements. The author wishes to thank all colleagues for making material available for study: Alfred Newton, Margaret Thayer and James Boone (FMNH); György Makranczy (HNHM); Giulio Cuccodoro (MHNG); Harald Schillhammer (NHMW); Wolfgang Schawaller (SMNS). I also thank Kirill Makarov for taking the photographs (Moscow Pedagogical State University, Russia).

\section{References}

Gildenkov M.Yu. 2014 (2013). [New species of the genus Carpelimus Leach, 1819 from the «silvestris» and «taprobanae» spe- cies groups (Coleoptera, Staphylinidae, Oxytelinae)] // Izvestiya Smolenskogo Gosudarstvennogo Universiteta. No.4(24). P.292305 [in Russian, with English summary].

Gildenkov M.Yu. 2015. [Fauna of Carpelimus of the Old World (Coleoptera: Staphylinidae)]. Smolensk: SmolSU. 414 pp. [In Russian, with English summary]

Gildenkov M.Yu. 2018. Five new species of the genus Carpelimus Leach, 1819, from the Oriental region (Coleoptera: Staphylinidae: Oxytelinae) // Russian Entomological Journal. Vol.27. No.2. P.135-142.

Gildenkov M.Yu. 2019. Five new species of genus Carpelimus Leach, 1819 from Thailand and the Philippines (Coleoptera: Staphylinidae: Oxytelinae) // Russian Entomological Journal. Vol.28. No.1. P 30-35. 